\title{
Jobs crisis sparks call for freeze in number of PhD students in US
}

[WASHINGTON] The number of life sciences $\mathrm{PhD}$ students in the United States should be frozen at current levels, recommends a report by the National Research Council. Trends in the Early Careers of Life Scientists, released today (10 September), says that increasing numbers of graduate students and postdoctoral fellows are failing to find long-term jobs.

Nearly four times more $\mathrm{PhDs}$ are being produced each year than in 1963 , with a 42 per cent rise between 1987 and 1996. Almost all the growth is in biomedical fields, and much is accounted for by foreign scientists. But jobs in the academic community, government and industry have not kept pace. There have been increases in the length of time taken to complete a $\mathrm{PhD}$, the average age at graduation, the numbers of young scientists taking up postdoctoral fellowships and the length of time spent as postdocs.

In 1973, about 11 per cent of PhDs still held postdoctoral or other non-faculty jobs at universities five to six years after graduating, or were outside science altogether. By 1995 , that number had risen to 38 per cent.

The report says that this situation has produced a "crisis in expectation" among young scientists. "The feelings of disappointment, frustration and even despair are palpable in the laboratories of academic centers," it says. "Further increase in the competition could discourage the best from entering the field."

The authors argue that even projected increases in government funding — for instance, an anticipated doubling of the budget of the National Institutes of Health - are unlikely to ensure any mitigating growth in permanent jobs. Nor, they say, can industry be counted on to hire more people, given recent trends.

They recommend that life sciences $\mathrm{PhD}$ programmes should not be expanded, and that no new programmes be started except in "rare and special circumstances", such as encouraging the education of underrepresented minorities.

"The current rate of growth can no longer be justified, and the premises that have produced it must be re-examined," the report says. "The system is delaying independence and muffling creativity at perhaps the most productive phase of the scientist's life."

If growth is not stopped, the report notes, the situation will only worsen: for instance, if the 5.1 per cent growth rate in $\mathrm{PhD}$ graduates between 1995 and 1996 were continued, the number of $\mathrm{PhD}$ graduates would double in 14 years.

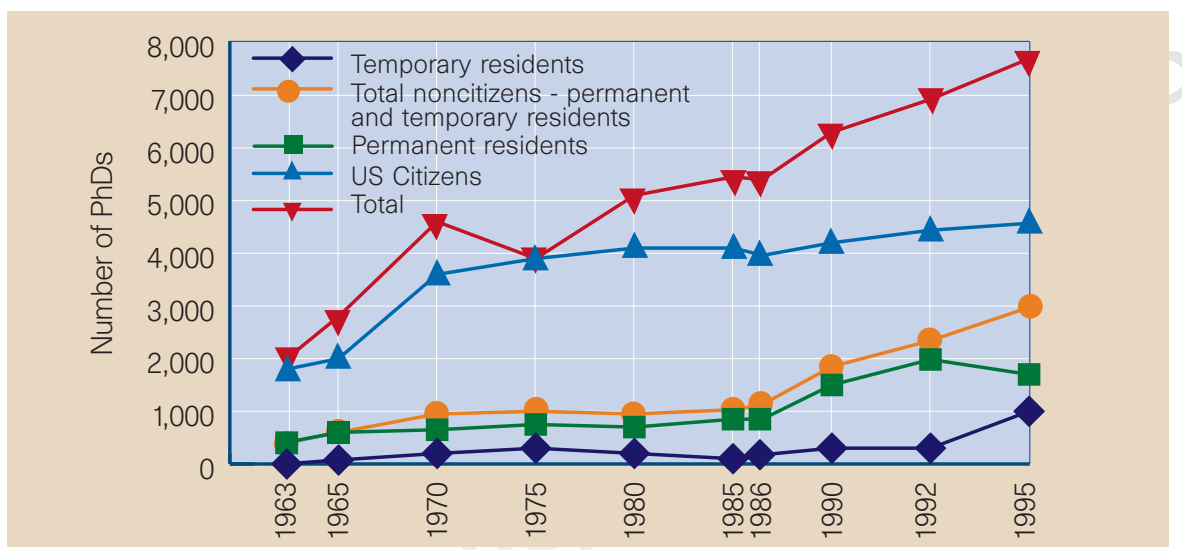

Population explosion: foreign students account for much of the growth in US life sciences PhDs.

William Brinkley, the president of the Federation of American Societies for Experimental Biology, and a member of the panel that wrote the report, says: "The hard facts are that across the life sciences we have a huge reservoir of outstanding people, capable of filling the needs that we see in the growth of science in the next few years."

The report urges universities to move towards using permanent, non-PhD technicians to carry out work now being done by graduate students and postdoctoral fellows. It also suggests that they consider restricting the numbers of graduate students supported by research grants.

Shirley Tilghman, a professor of molecular biology and a Howard Hughes Medical Institute investigator at Princeton University, who chaired the 16-member panel that wrote the report, blames the structure of the US research enterprise, in which senior scientists rely on cadres of young graduate students and some 20,000 postdocs to staff their laboratories at bargain rates.

"We are creating this working class who are absolutely essential to the conduct of research, and yet they are spending many years in positions which we would not consider on some kind of a career trajectory."

Tilghman likens the situation of postdocs to jets above an airport: "They are circling, using up fuel and waiting for their turn to land. We have to think hard about the ways in which we have allowed what were supposed to be training positions to become these kinds of holding-pattern positions."

But some in the field question whether a moratorium on $\mathrm{PhD}$ programme growth would be accepted by institutions and senior scientists now heavily reliant on young scientists for carrying out research.

"It's difficult to tell people to stop training people when they look at a trainee and think: 'this is how we get our work done', says Frank Solomon, a professor of biology at the Massachusetts Institute of Technology who chairs the education committee of the American Society for Cell Biology.

Others question whether the crisis described in the report has reached the proportions that would require a freeze on $\mathrm{PhD}$ programmes. "We cannot predict future job opportunities and therefore we cannot say when we're going to need to enter the steady state. We don't want to turn away bright young people because of a negative press," says Susan Gerbi, chair of the department of molecular biology, cell biology and biochemistry at Brown University in Providence, Rhode Island.

The report says that graduate programmes should be required to confront prospective students with the hard facts of their career prospects, by providing data on the careers of $\mathrm{PhD}$ graduates over the previous 10 years. The information "will have the salutary effect of letting market forces control the rate of entry into the profession".

And the report urges government agencies to shift towards funding more broadbased training grants and individual fellowships, with fewer of the research grants that have almost entirely fuelled the growth in the number of $\mathrm{PhD}$ trainees over the past 10 years. While attractive to institutions as sources of funded students, these do less for the student, the report says.

The report dismisses the notion that $\mathrm{PhD}$ programmes should be broadened to prepare graduates for alternative careers that, it maintains, do not require a $\mathrm{PhD}$.

The report says foreigners accounted for most of the increase in $\mathrm{PhD}$ graduates since 1987. But it urges that this should not lead to "arbitrary limitations on the number of visas issued for foreign students". Meredith Wadman 